\title{
MANDUME: A visualidade do rap como resistência contra o epistemicídio
}

Edição v. 38

número 2 / 2019

Contracampo e-ISSN 2238-2577

Niterói (RJ), 38 (2)

ago/2019-nov/2019

A Revista Contracampo é uma revista eletrônica do Programa de Pós-Graduação em Comunicação da Universidade Federal Fluminense e tem como objetivo contribuir para a reflexão crítica em torno do campo midiático, atuando como espaço de circulação da pesquisa e do pensamento acadêmico.

\section{MANDUME: Rap's visuality as resistance against epistemic violence}

\section{LUCIANNA FURTADO}

Doutoranda do Programa de Pós-Graduação em Comunicação Social da Universidade Federal de Minas Gerais (PPGCOM-UFMG) e mestra em Comunicação Social pela mesma instituição. Integrante do CORAGEM Grupo de Pesquisa em Comunicação, Raça e Gênero. Belo Horizonte, Minas Gerais, Brasil. E-mail: lucianna.furtado@gmail.com. ORCID: https://orcid. org/0000-0002-4818-9370.

AO CITAR ESTE ARTIGO, UTILIZE A SEGUINTE REFERÊNCIA:

FURTADO, Lucianna. MANDUME: A visualidade do rap como resistência contra o epistemicídio. Contracampo, Niterói, v. 38, n.2 p. 66-84, ago./nov. 2019.

Enviado em 22/2/2019/Revisor A: 1/7/2019; Revisor B: 22/7/2019 / Revisor A: 12/08/2019; Revisor B: 17/07/2019; Aceito em 19/8/2019 


\section{Resumo $^{1}$}

Este artigo discute os refrões do videoclipe Mandume (2016) a partir das noções de metaimagem, do composto imagem-texto e dos efeitos performativos dos atos de ver, aliando as contribuições dos Estudos Visuais à análise de estilo televisivo. Ao abordar a produção audiovisual do rap, a proposta do trabalho é centralizar vozes e perspectivas historicamente silenciadas, evidenciando as relações entre os aspectos formais e culturais da experiência visual. O trecho analisado compreende os refrões em suas recorrências e as narrativas visuais que os acompanham, investigando o que essa manifestação da cultura popular revela sobre as relações raciais em nossa sociedade.

Palavras-chave

Rap; Relações raciais; Racismo; Cultura visual; Epistemicídio.

\section{Abstract}

This paper discusses the chorus from the music video Mandume (2016), guided by the notions of metapicture, image-text and the performative effects of the acts of seeing, associating the contributions of Visual Studies to television stylistic analysis. By approaching rap's audiovisual production, this work intends to centralize historically silenced voices and perspectives, highlighting the relations between the visual experience's formal and cultural elements. The excerpt analyzed comprises the choruses, in their recurrences, and their visual narratives, inquiring what this popular culture expression reveals about racial relations in our society.

Keywords

Rap; Racial relations; Racism; Visual culture; Epistemicide.

\footnotetext{
${ }^{1}$ Este artigo divulga uma parte das discussões da minha dissertação de mestrado (FURTADO, 2019), produzida com apoio financeiro do Conselho Nacional de Desenvolvimento Científico e Tecnológico (CNPq), concedido por meio de bolsa durante o curso.
} 


\section{Introdução}

O material discutido neste artigo é o videoclipe Mandume (2016), dos rappers Emicida, Drik Barbosa, Amiri, Rico Dalasam, Muzzike e Raphão Alaafin, dirigido por Gabi Jacob. O título faz referência ao rei Mandume ya Ndemufayo, líder contra as missões evangelizadoras e invasões coloniais portuguesas e alemãs na região hoje nomeada como Angola, resgatando a memória cultural da matriz africana para articular junto às pessoas negras uma visão heroica, de poder e resistência da própria ancestralidade e cultura. O videoclipe não aborda diretamente a história de Mandume, mas seu valor simbólico, fazendo uso do seu apagamento na historiografia tradicional para tratar da violência contemporânea contra pessoas negras - evidenciando o que há de Mandume em nós e o que deve haver da história de Mandume em nossa própria história.

O videoclipe Mandume foi produzido como um fashion film da coleção Yasuke, da grife do Laboratório Fantasma, um coletivo de amantes da arte urbana e fãs do hip hop que, além da grife, agencia a produção de CDs, videoclipes e eventos musicais. ${ }^{2}$ O nome da coleção é uma referência a Yasuke, guerreiro africano levado à força pelos jesuítas para o Japão no século XVI, que se tornou o primeiro samurai estrangeiro e conquistou status de lenda por sua habilidade, força e invencibilidade. ${ }^{3} \mathrm{~A}$ coleção foi apresentada na São Paulo Fashion Week em 2016, mesclando referências africanas e orientais na composição das peças.

Em entrevista à revista Le Monde Diplomatique Brasil ${ }^{4}$, Emicida explica que o Lab Fantasma privilegia pessoas negras em toda a cadeia de produção, "da costureira da Vila Brasilândia à modelo que desfilou", movendo toda a estrutura e colocando "esses pretos vivos na capa de todos os jornais do Brasil", em oposição às representações de pessoas negras de forma confinada à violência e miséria. Assim, o afroempreendedorismo emerge como um modo de romper com a hegemonia econômica da branquitude, em relações de trabalho mais justas e inclusivas, bem como um meio para a construção de outras narrativas, outros modos de ocupar espaços de visibilidade.

As próximas seções apresentam as contribuições dos Estudos Visuais para abordar a visualidade, as noções de metaimagem, interação entre imagem e texto e os efeitos performativos dos atos de ver. Em seguida, a análise interroga a materialidade visual sobre o que revela acerca das relações raciais em nossa sociedade, por meio da análise estilística televisiva.

\section{A visualidade, as interações imagem-texto e as metaimagens}

Na perspectiva do pesquisador William J. T. Mitchell (2017), as experiências do olhar são processos culturais socialmente construídos por meio da interação entre o sentido da visão e a história da arte, a tecnologia, os meios de comunicação e as práticas sociais de ver e mostrar; de se posicionar como espectador e de construir formas de dar a ver. Nesse sentido, o autor propõe um conceito dialético do termo "cultura visual": em vez de pensar na construção social de um campo visual, ele defende investigar a construção visual de um campo social.

Apesar de enfatizar essa dimensão visual, Mitchell (2005) destaca que todos os meios são mistos, compostos por elementos sensoriais, perceptivos e semiótico-discursivos inseparáveis. Isto não indica que os meios são indiscerníveis: para o autor, é nas diferentes mesclas entre as percepções sensoriais que se encontra a especificidade do meio. Para Mitchell, essa abordagem permite melhor analisar as tecnicidades, práticas e funções na construção visual, e as condições de produção e consumo que

\footnotetext{
2 Disponível em: www.labfantasma.com/noiz. Acesso em: 25 nov. 2018.

${ }^{3}$ Disponível em: bit.ly/2QoL4hm. Acesso em: 25 nov. 2018.

${ }^{4}$ Disponível em: bit.ly/2KwwjUc. Acesso em: 25 nov. 2018.
} 
constituem o meio - sem se prender a uma única via sensorial, mas tomando a materialidade enquanto um composto híbrido, como é apresentada ao espectador. O autor propõe que a visualidade contemple sua inseparabilidade do texto, do verbal, do sonoro, tomando-a como um composto de imagem-texto, observando como se constrói a interação, combinação e interligação entre esses aspectos. Mitchell ressalta que a proporção sensorial da visão se complexifica ainda mais na dimensão emocional, dos afetos e encontros intersubjetivos entremeados ao campo visual que permeiam os atos de olhar, ver e mostrar.

Tomando as práticas visuais como atos sociais culturalmente instituídos, José Luis Brea (2005) propõe uma desconstrução da articulação social e cognitiva que as constituem. O autor defende que não existem objetos, fenômenos ou meios de visualidade pura, mas atos de ver complexos e atravessados por imbricações sensoriais e simbólico-discursivas. Em sua concepção, esses atos de ver resultam da cristalização do entrelaçamento de operadores textuais, mentais, imaginários, sensoriais, mnemônicos, midiáticos, técnicos, burocráticos e institucionais; amalgamados junto às relações sociais de representação em disputa, que Brea especifica como interesses de raça, gênero, classe, diferença cultural, crenças e afinidades, dentre outros.

Assim, Brea (2005) define os atos de ver como construções culturais híbridas, socialmente instituídas, que articulam relações de poder, dominação, privilégio e subalternidade. A importância desses atos de ver reside em sua capacidade de produzir realidades e provocar efeitos de subjetivação e socialização, que Brea chama de força performativa - realizada na interação entre os sujeitos e a visualidade de forma culturalmente estruturada, por meio dos processos de identificação e diferenciação frente aos imaginários hegemônicos, minoritários e contra-hegemônicos em circulação na sociedade. 0 autor destaca a relevância de interrogar criticamente como esses efeitos performativos articulam impactos políticos em sua produção de formas de subjetivação e sociabilidade.

O encontro com a visualidade é instrumentalizado por Brea (2005) como um encontro com o outro, em que o sujeito constitui a si mesmo em relação a esse outro, que também olha de volta. Permeado e tensionado pelas dinâmicas de identificação e diferenciação, esse encontro instaura identidades e políticas de posicionalidade quanto à visualidade, seus valores e significações. O autor evidencia, assim, o caráter intersubjetivo das imagens, inscrevendo socialmente a presença desse outro e estruturando a dimensão socializada, coletiva, dos processos identitários realizados nos atos de ver. Brea identifica que há epistemes escópicas nas quais esses atos se inscrevem, um conjunto de conhecimentos que condicionam culturalmente os regimes de visibilidade e as ações dos sujeitos diante deles. Para o autor, tais ações se dão em uma dimensão social de interação com a alteridade, em que se pode reiterar ou redefinir, subverter e romper com os códigos existentes.

Para Brea (2005), portanto, a experiência visual é construída na interação entre o espectador e a materialidade visual, permeada por determinações culturais, preconcepções e memórias. Em diálogo com o aporte teórico de Lacan, Brea considera que há algo entre o sujeito que olha e aquele que é olhado e devolve o olhar: uma espécie de tela, um repertório de imagens e imaginários culturalmente produzidos, por meio da qual os sujeitos constituem a si mesmos e aos outros, se diferenciando em termos de categorias identitárias estruturais, acionando representações dominantes ou tensionando-as. Os modos como essa tela permeia os processos de subjetivação e socialização condicionam, assim, a necessidade de historicizar a experiência visual junto às determinações da vida social.

Partindo da noção de que a linguagem diz algo sobre si mesma, Mitchell (2009) elabora a metaimagem: imagens autorreferenciais, com o potencial de evidenciar algo sobre si mesmas ou sobre outras imagens, formas de construção de imagens, modos de ver e mostrar - compondo um discurso de segunda ordem que revela algo sobre as imagens, seus processos de produção e as práticas de representação visual. Mitchell considera que as metaimagens mostram a si mesmas para dar-se a conhecer, 
encenando o autoconhecimento das imagens e provocando o autoconhecimento do espectador, que completa a picture ${ }^{5}$ em seu encontro com ela.

Na concepção do autor, ao apresentar abertura para leituras distintas, a multiestabilidade das metaimagens provoca o emergir da identidade do observador em diálogo com estereótipos culturais, ideologias e imaginários em circulação na sociedade. Desse modo, ao perguntar "o que sou?" e "como me vê?", a imagem demanda que o espectador dirija a si mesmo tais perguntas. O diálogo entre o observador e a metaimagem não acontece "em um terreno incorpóreo à margem da história, mas estão inscritas em discursos, disciplinas e regimes de conhecimento específicos" (MITCHELL, 2009, p. 50, tradução nossa). Assim, a experiência visual é permeada pelos aparatos culturais, epistemológicos e subjetivos que constituem a inserção sócio-histórica do sujeito.

Nessa linha de pensamento, Mitchell (2009) diferencia três categorias de autorreferencialidade da metaimagem na representação visual: a imagem que representa a si mesma em um círculo referencial; a imagem genericamente autorreferencial que representa as imagens como classe, ou seja, uma imagem sobre as imagens; e uma autorreferência contextual ou discursiva, em que sua reflexividade envolve considerações sobre a natureza da representação visual. O autor destaca, porém, que a autorreferência não é uma característica exclusivamente formal de imagens específicas, mas um elemento funcional, pragmático, de uso e contexto - de modo que qualquer imagem usada para refletir sobre a natureza das imagens pode ser considerada como uma metaimagem.

Para Mitchell (2009), a principal função das metaimagens é explicar algo sobre as imagens, encenar seu autoconhecimento, que, por sua vez, leva ao autoconhecimento do observador. O autor aponta essa capacidade de desestabilizar a identidade como uma questão fenomenológica, que acontece na interação entre os espectadores e a materialidade visual devido aos efeitos da sua multiestabilidade, ou seja, sua capacidade de comportar formas distintas de ser vista; formas divergentes e mesmo paradoxais de ser apreendida. Assim, as metaimagens usam seu autoconhecimento para acionar o autoconhecimento do espectador, interrogando a identidade de sua posição como tal.

Mais do que o encontro entre os olhos e as imagens, Mitchell (2009) enfatiza que o questionamento acerca dos efeitos e da identidade envolve a posição da metaimagem no campo cultural, seu lugar em relação às disciplinas, discursos e instituições. Segundo o autor, as metaimagens ocupam espaços diversos, desde as culturas populares ao saber letrado da ciência, filosofia e história da arte; desde posições marginais e secundárias a centrais e canônicas. A metaimagem de Mitchell, portanto, "é o lugar onde as imagens se revelam e se conhecem, onde refletem sobre as interseções entre a visualidade, a linguagem e a semelhança, onde especulam e teorizam sobre sua própria natureza e história" (2009, p. 77, tradução nossa); não meramente ilustrando teorias, mas dando imagem à teoria.

\section{Propostas analíticas para as televisualidades}

Apesar do consumo de videoclipes ter migrado dos canais musicais para a internet, Thiago Soares $(2007,2013)$ destaca que o videoclipe mantém suas principais características culturais e musicais vinculadas a sua origem como um gênero televisivo. O autor enfatiza que as dimensões plásticas e midiáticas do videoclipe estão circunscritas no universo da televisão, segundo lógicas e modos de produção de sentido televisivos articulados com o gênero musical - acionando relações de reconhecimento, consumo e identificação de maneira híbrida, a partir dessa dupla orientação.

\footnotetext{
${ }^{5}$ Nas versões originais de suas obras, em inglês, Mitchell diferencia os termos picture (sem correlato no português) e image (imagem): o primeiro se refere ao domínio das imagens materiais, gráficas e óticas, que se manifestam por meio de suportes materiais "que podem ser penduradas na parede, impressas numa página ou destruídas"; enquanto este último diz respeito às imagens imateriais, mentais e verbais, como fantasias, sonhos, memórias e visualizações de símiles e metáforas. Na concepção do autor, a picture e a imagem se interseccionam no domínio da imagem perceptual, localizada na fronteira entre as realidades material e mental (MELO ROCHA e PORTUGAL, 2009, p. 5-7).
} 
Para Jeder Janotti Júnior e Thiago Soares (2008), o estudo de videoclipes deve considerar a dimensão imagética e a musical, por se originar precisamente desse encontro. Os autores propõem pensar no videoclipe como extensão da canção, que articula significados, referências e institui princípios visuais específicos ao gênero musical. Em sua visão, os videoclipes de hip hop costumam se ambientar no universo cultural das periferias urbanas, das ruas, muros e asfalto, acionando elementos como o grafite e a pichação. Desse modo, a visualidade referencia outros aspectos que permeiam as gramáticas culturais da música, articulando o que Janotti Júnior e Soares (2008) descrevem como as formas, estilos e traços das práticas de produção, circulação, reconhecimento e consumo de cada gênero musical. Nesse sentido, Soares (2013) propõe pensar o videoclipe em termos relacionais entre imagem e som, buscando apreender seus entrelugares.

A partir dos Estudos Visuais, Simone Rocha (2016, 2017) propõe uma análise ancorada na não disjunção das dimensões formais e culturais dos produtos televisuais, articulando a construção de significados no encontro entre os espectadores e a materialidade como interações permeadas pela cultura. Essa perspectiva centraliza a especificidade cultural da visualidade, contextualizando a visão, os modos de ver e dar a ver como práticas sociais culturalmente estruturadas. A autora combina a noção de visualidade à análise formal do estilo televisivo, conforme proposta por Jeremy Butler (2010), evidenciando a complexidade dos produtos televisuais e seus entrelaçamentos contextuais.

Na perspectiva de Butler (2010), "estilo" se refere aos modos como os aspectos formais da composição de imagem e som são operados para cumprir determinadas funções, sistematizando como os códigos estilísticos - técnicos e sociais - atuam na construção de significações culturais. Segundo o autor, esses padrões tratam de convenções estilísticas que constituem gramáticas socialmente compartilhadas, articulando as práticas de produção e consumo de produtos televisivos. Nesse contexto, Butler propõe uma engenharia reversa, desconstruindo a produção televisiva e observando como essas técnicas são utilizadas.

Butler (2010) adapta as contribuições de David Bordwell, no cinema, para as especificidades do estilo televisivo, sistematizando quatro dimensões da análise: a descritiva, a analítica (ou interpretativa), a avaliativa (ou estética), e a histórica. A descrição do enquadramento, movimentos de câmera, edição e outros aspectos da composição audiovisual é o primeiro passo apontado pelo autor, articulando as dimensões técnicas aos códigos sociais e valores culturais. Butler destaca que a descrição estilística acaba, por si só, conduzindo à interpretação, iniciando e fundamentando a etapa seguinte, a analítica.

A dimensão analítica, segundo Butler (2010), envolve o propósito dos elementos estilísticos e o desempenho de funções no texto audiovisual. Partindo da definição de Bordwell das quatro funções do estilo no cinema - denotar, expressar, simbolizar e decorar - Butler acrescenta outras quatro, específicas à televisão: persuadir, interpelar, diferenciar e dar sentido de "ao vivo". A etapa avaliativa se apresenta como um desafio, na medida em que o autor considera que os estudos televisivos não sistematizaram normas capazes de resistir à hierarquização estética elitista. Já a dimensão histórica consiste em um recuo temporal para revelar um contexto mais amplo do estilo televisivo, demonstrando como os aspectos econômicos, tecnológicos, industriais e semiótico-estéticos interferem em seus padrões.

A proposta analítica elaborada por Rocha $(2016,2017)$ defende que os modos de ver e dar a ver instituídos na experiência visual podem revelar determinações políticas, históricas e culturais. Para a autora, a análise da televisualidade permite emergir o que está para além de seus limites, em circulação nas relações de poder, regimes de socialização e imaginários culturais em disputa. Desse modo, observase como as características materiais do arranjo entre imagem e som cumprem funções específicas nos dispositivos junto às condições imateriais e culturais que permeiam as práticas visuais.

Aliando a análise de estilo televisivo aos Estudos Visuais, Rocha (2017) propõe tomar as relações entre imagem e texto como uma abertura na representação, uma brecha por onde emerge a história que costura o composto imagem-texto. A autora aponta que a análise do estilo televisivo (BUTLER, 2010) 
é compatível com o composto imagem-texto (MITCHELL, 2005), na medida em que ambas partem da descrição formal para a análise funcional do arranjo de imagem e som, que demanda respostas que não são universais, mas históricas, social e culturalmente contextualizadas. Na visão de Rocha (2017), o foco na dimensão analítica funcional permite abordar a relação entre imagem e texto como locus de um conflito, para vislumbrar as disputas políticas, institucionais e sociais entremeadas à representação.

\section{Mandume}

Esta seção discute o videoclipe Mandume (2016), dos rappers Emicida, Drik Barbosa, Amiri, Rico Dalasam, Muzzike e Raphão Alaafin, e direção de Gabi Jacob. Diante do volume extenso do material televisivo, Rocha (2016) propõe delimitar unidades mais curtas para direcionar o exercício analítico. Para a autora, pode-se selecionar um conjunto de eventos narrativos específicos que compõem uma trama ou subtrama, que podem estar em uma mesma cena, sequência, ou na articulação de sequências separadas temporalmente. Para este artigo, foram escolhidos os refrões de Mandume, com o objetivo de observar o que a oralidade e a visualidade desses trechos revelam sobre as relações raciais no contexto cultural brasileiro. A discussão foca nas etapas descritiva e analítica, considerando as dificuldades dos estudos televisivos em sistematizar critérios para a análise valorativa, como apontado por Butler (2010), e a limitação de espaço que impede o recuo temporal da análise histórica. Na relação entre imagem e texto, este trabalho se concentra nos aspectos da visualidade e na dimensão semântica das palavras cantadas.

No refrão de Mandume, os rappers cantam:

Eles querem que alguém

Que vem de onde nóiz vem

Seja mais humilde, baixe a cabeça

Nunca revide, finja que esqueceu a coisa toda

Eu quero é que eles se ----! ${ }^{6}$

O refrão é cantado em bis, somando três pares no total. Após a abertura que acompanha a introdução, a cena do primeiro refrão se inicia em fade-in, mostrando duas mulheres de costas, com um muro de tijolos expostos coberto por pichações ao fundo (frame 1). Uma delas tem o cabelo longo e trançado, a outra usa o cabelo crespo, volumoso, em estilo black power. Ambas usam peças do Lab Fantasma, uma com a palavra "Ubuntu"7 estampada, e se viram para lançar seus olhares à câmera (frame 2).

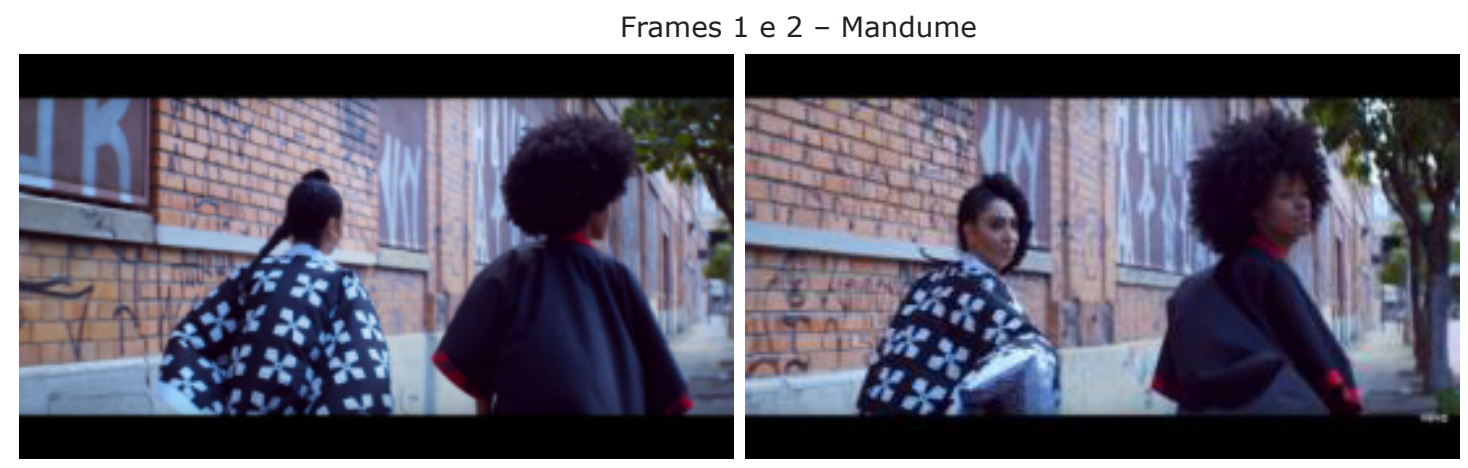

Fonte: youtu.be/mC_vrzqYfQc. Acesso em: 10 jan. 2019.

\footnotetext{
${ }^{6}$ Refrão da música "Mandume". Disponível em: bit.ly/2DZORf1. Acesso em: 27 nov. 2018.

7 O termo "ubuntu", do zulu, significa humanidade para com os outros, ou a ideia de que "uma pessoa é uma pessoa por meio de outras pessoas". Trata-se de um fundamento da tradição filosófica africana ancorado na noção de humanidade como princípio ético de respeito à comunidade, à coletividade de outros seres humanos. Nessa perspectiva, uma pessoa tem consciência de que também é afetada quando seus semelhantes são oprimidos. Disponível em: bit.ly/2GeJV7W. Acesso em: 11 dez. 2018.
} 
A cena seguinte mostra sete homens e mulheres em frente a um muro de tijolos aparentes, com cabelos crespos naturais, em black power e dreads ou bonés, uma arrumando orgulhosamente o cabelo para intensificar seu volume, e outra segurando um bebê (frame 3). A composição anterior, que mostrava as mulheres de costas, virando para devolver o olhar à câmera, dá lugar ao plano frontal nesse momento. Além de duas camisetas com a inscrição "Ubuntu", um dos rapazes usa uma camiseta com a frase "o hip hop é foda!". A sequência continua para close ups de dois dos rapazes (frame 4), em contra-plongée; e enquadra aos sete novamente, que mantêm os olhares dirigidos à câmera, com expressões faciais intensificadas e braços cruzados. Durante o verso "eu quero é que eles se ----!", um deles levanta os dedos do meio em direção à câmera (frames 5 e 6).

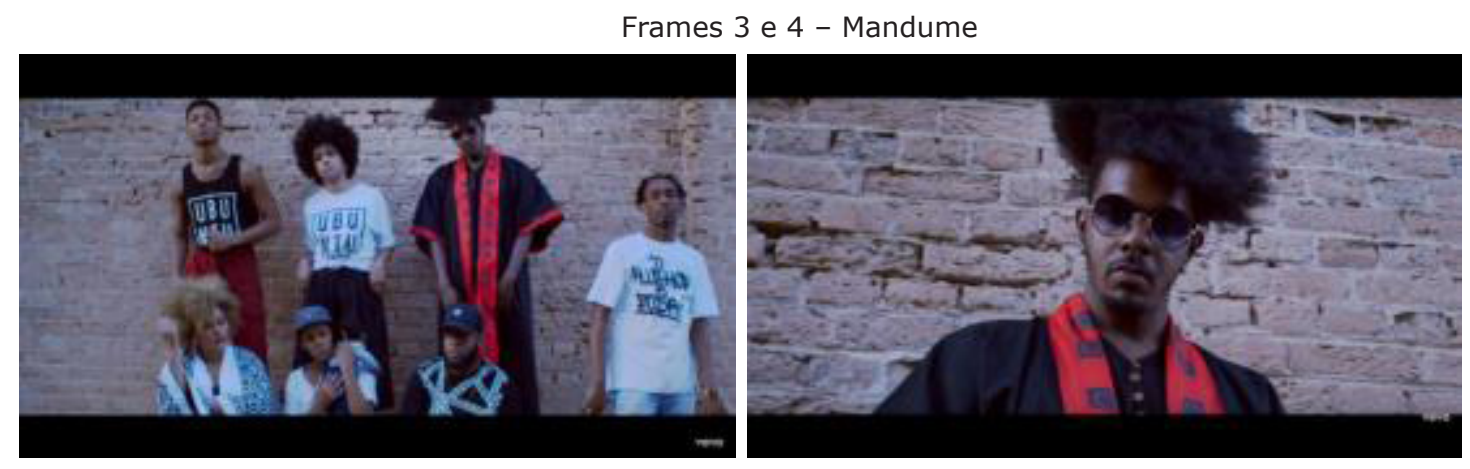

Fonte: youtu.be/mC_vrzqYfQc. Acesso em: 10 jan. 2019

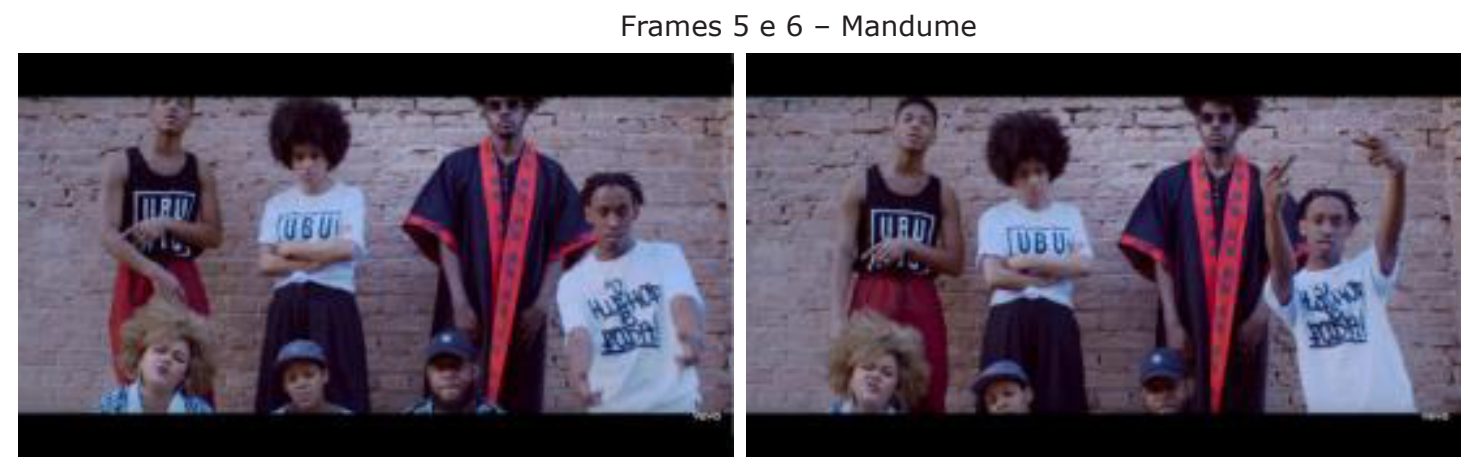

Fonte: youtu.be/mC_vrzqYfQc. Acesso em: 10 jan. 2019.

No bis, o cenário muda para uma boate com uma luz azulada ao fundo, intercalando um plano com um grupo de mulheres e outro com um grupo de homens. Conforme o ângulo se afasta em zoom out e enquadra cada vez mais pessoas, são reiterados elementos da estética cultural negra: cabelos cacheados ou crespos, em black power e dreadlocks, e as camisetas trazem, além de "ubuntu", as palavras "\#musa", "quebrada" e "I love quebrada". Também são reforçados os olhares fixos à câmera, com braços cruzados ou no movimento de cruzá-los (frames 7 e 8). As cenas seguintes intercalam duas mulheres de vermelho em frente a uma cerca viva, olhando uma para a outra com seriedade, e um casal vestindo camisetas do Lab Fantasma do mesmo modelo, mas com cores diferentes. O casal é enquadrado em contra-plongée, com galhos de árvores se estendendo ao fundo, por trás de suas figuras. Em todas estas cenas, mantém-se o plano frontal, privilegiando os rostos, posturas e olhares dos sujeitos. 
Frames 7 e 8 - Mandume

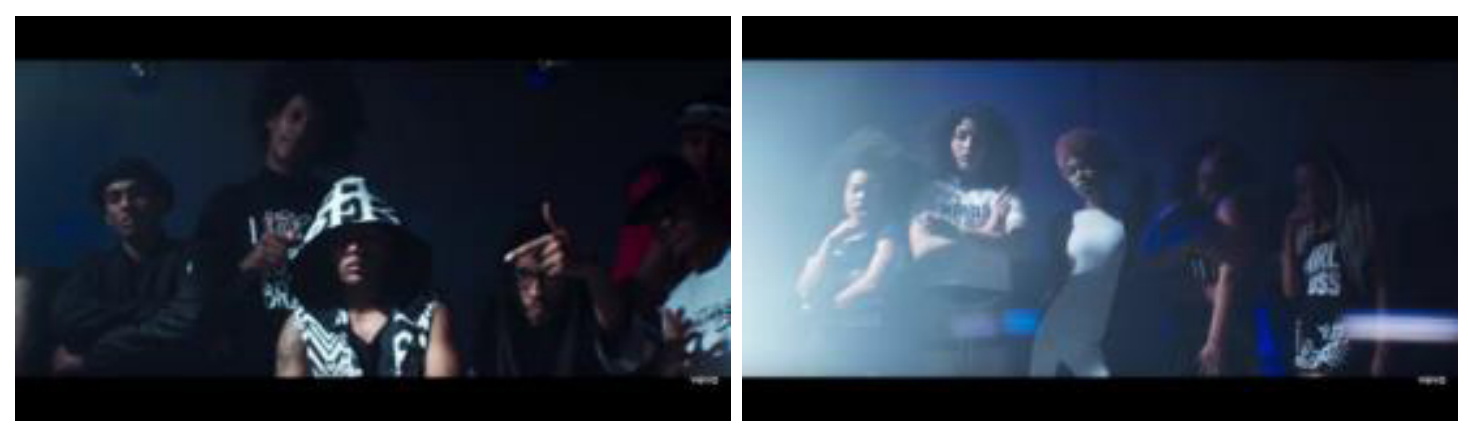

Fonte: youtu.be/mC_vrzqYfQc. Acesso em: 10 jan. 2019.

A sequência prossegue para um quadro com quatro mulheres negras, em plano frontal, em frente a uma parede de tijolos aparentes, com peles de tonalidades distintas e estilos de cabelos variados: uma usa um turbante vermelho e branco e uma blusa com a inscrição "LAB"; uma usa o cabelo crespo raspado curto e uma blusa com a palavra "ubuntu"; outra traz o cabelo trançado com degradê em rosa e a camiseta "I love quebrada"; a outra usa o cabelo cacheado volumoso e uma camiseta estampada com um menino negro, vestido e sentado como um monge (frame 9). Outros elementos que sugerem a diversidade entre elas são as posições, poses e ângulos diferentes que ocupam no plano, enquanto os olhares e expressões faciais as aproximam sob a ideia de uma luta compartilhada - que, devido à letra da música junto a sua identificação racial, sabemos se tratar da opressão racista. Este refrão se encerra com a mulher de turbante se aproximando da câmera, gesticulando um "não" (frame 10), enquanto as outras sustentam firmemente o olhar ao fundo, intercalando-se com a rapper que performa o primeiro solo.

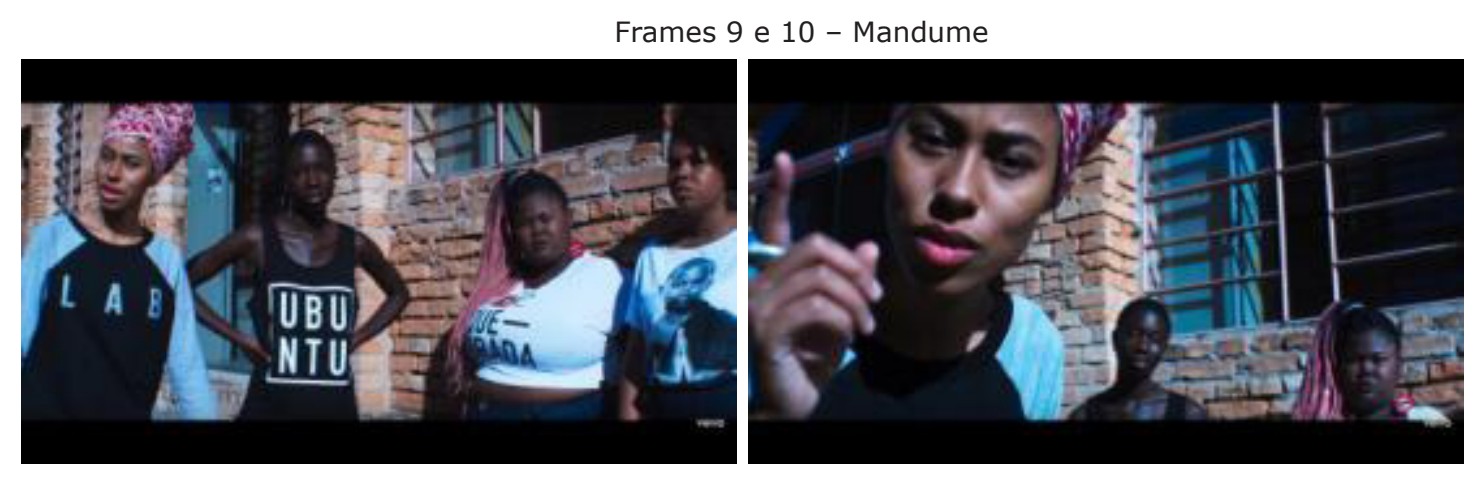

Fonte: youtu.be/mC_vrzqYfQc. Acesso em: 10 jan. 2019.

Após os solos de Drik Barbosa, Amiri e Rico Dalasam, o segundo refrão retorna com um rapaz sem camisa, abrindo em zoom out para enquadrar também seu rosto sério. Em seguida, foca um homem de olhar fixo em direção à câmera, um pouco à frente de uma mulher de cabelo crespo e curto que também encara e devolve o olhar à câmera (frame 11); o foco passa a outro homem com uma expressão semelhante, à frente de uma mulher de dreadlocks (frame 12). O enquadramento seguinte mostra os quatro sentados em uma escadaria com pichações e grafites nas laterais e árvores ao fundo, as mulheres posicionadas no centro, aparentemente um degrau acima dos homens (frame 13). 
Frames 11 e 12 - Mandume

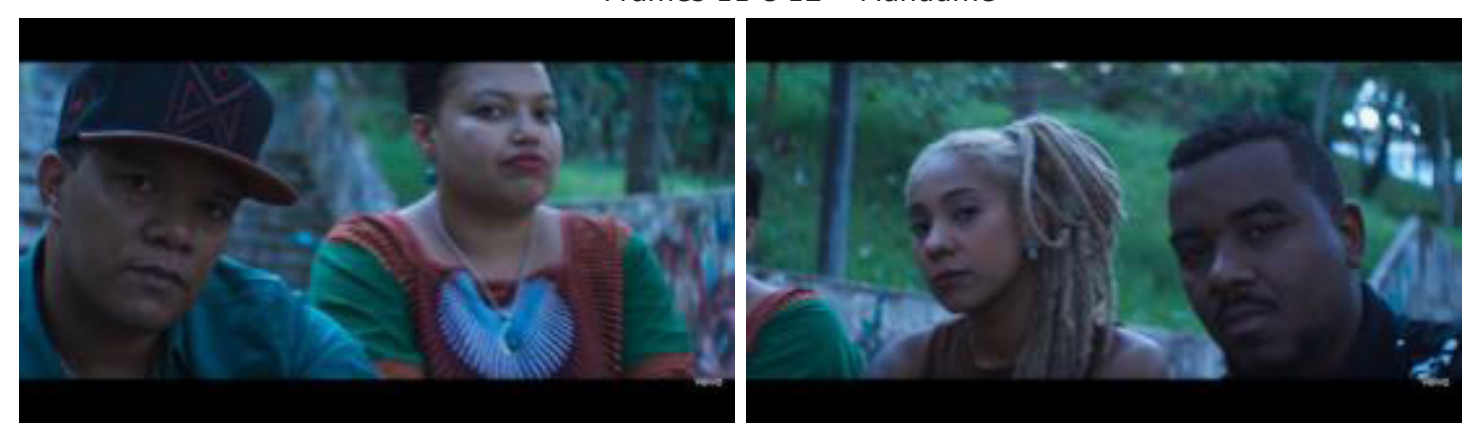

Fonte: youtu.be/mC_vrzqYfQc. Acesso em: 10 jan. 2019.

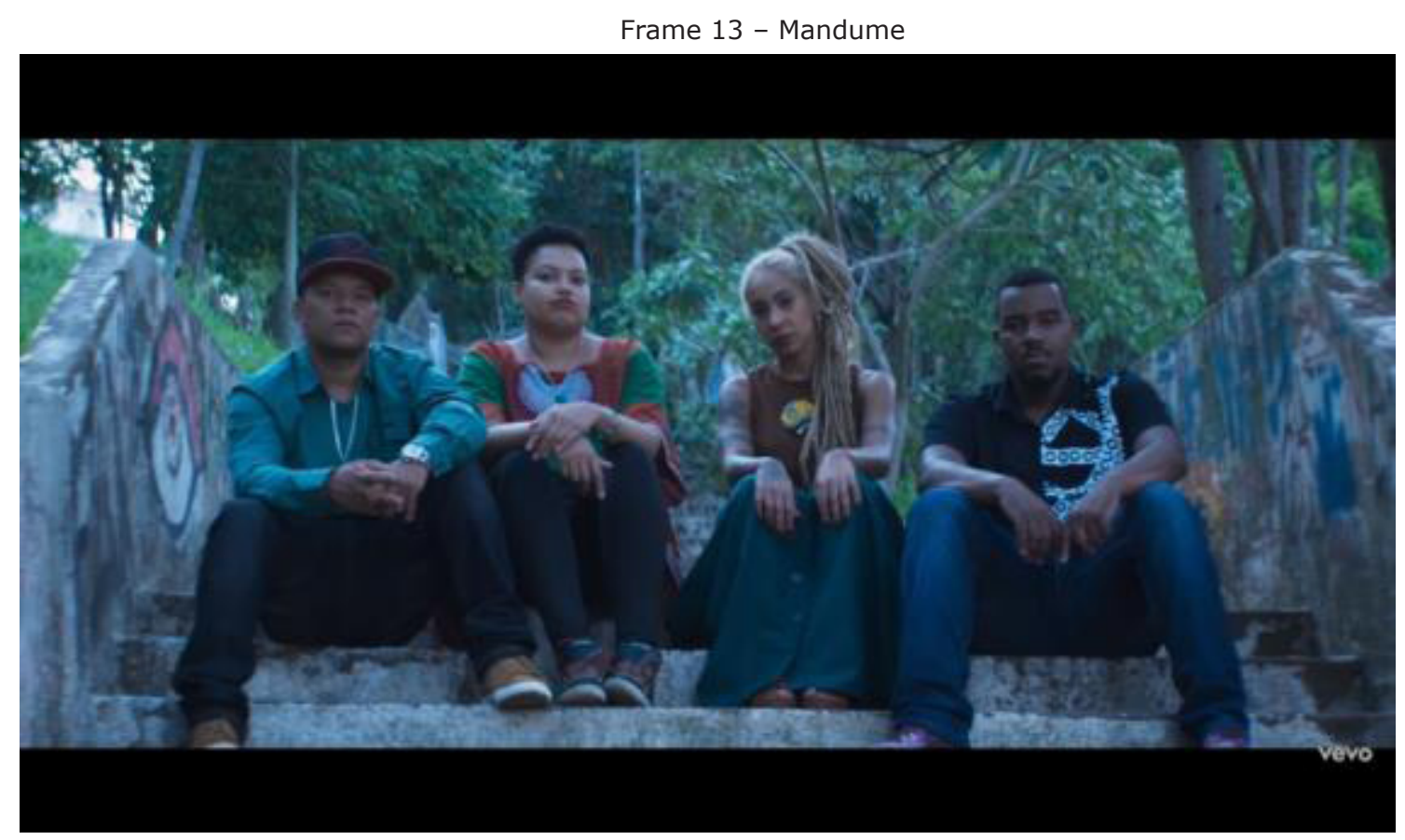

Fonte: youtu.be/mC_vrzqYfQc. Acesso em: 10 jan. 2019.

Os homens parecem guardá-las, protegê-las de algo ou alguém que se encontra fora de quadro ou na posição da câmera e do espectador - alguém não mostrado, deixado para que as representações que compõem os repertórios e imaginários dos espectadores informem quem está fora dali e por que convoca essa posição. A cena seguinte mostra uma mulher de cabelo crespo curto e um homem com um boné do Lab Fantasma em frente a um portão metálico, com olhares firmes para a câmera. Em seguida, em primeiro plano, eles intensificam suas expressões faciais, culminando em gestos com os dedos do meio juntamente à última frase do refrão: "eu quero é que eles se ----!".

No bis, uma moça de cabelos trançados beija um rapaz de cabelo crespo em um cenário gramado, com árvores ao fundo (frame 14). As duas mulheres que abrem a cena do primeiro refrão retornam à narrativa agora de frente para a câmera, com seus olhares e posturas corporais intensificados, uma delas com a mão na cintura (frame 15). As mulheres de vermelho em frente à cerca viva também retornam, agora dirigindo o olhar sério para a câmera (frame 16), uma delas de braços cruzados, em seguida, olhando uma para a outra com um riso de cumplicidade (frame 17): ao se unirem contra o inimigo comum, constrói-se entre elas uma relação afetuosa e amigável. O grupo dos sete também retorna à cena de braços cruzados e olhares intensificados, seguido pelo foco em quatro deles com a câmera levemente posicionada em contra-plongée, mostrando gestos negativos e expressões faciais ainda mais enfáticas. 
Frames 14 e 15 - Mandume

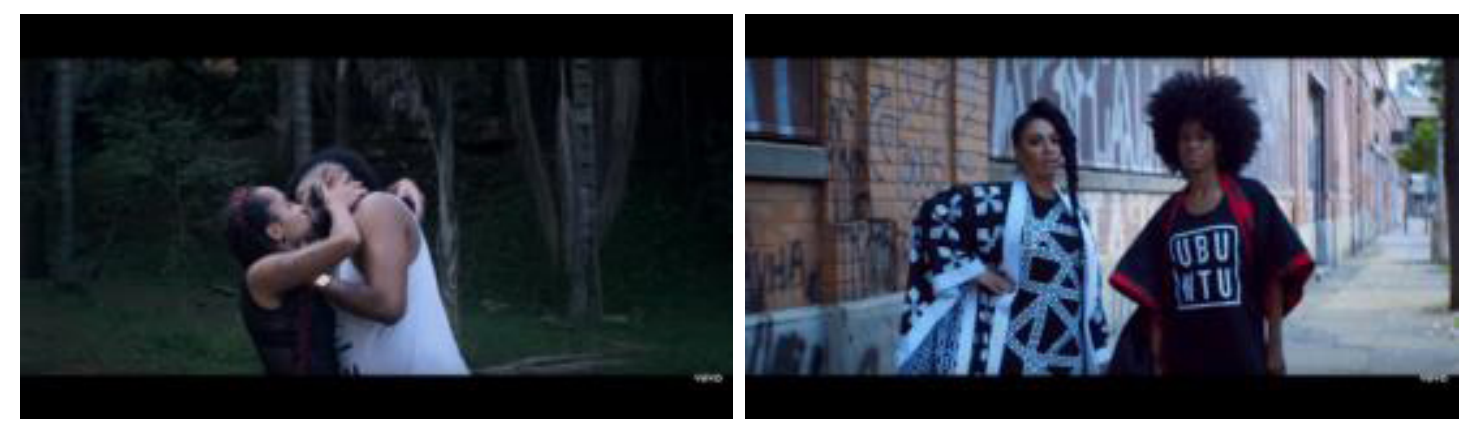

Fonte: youtu.be/mC_vrzqYfQc. Acesso em: 10 jan. 2019.

Frames 16 e 17 - Mandume

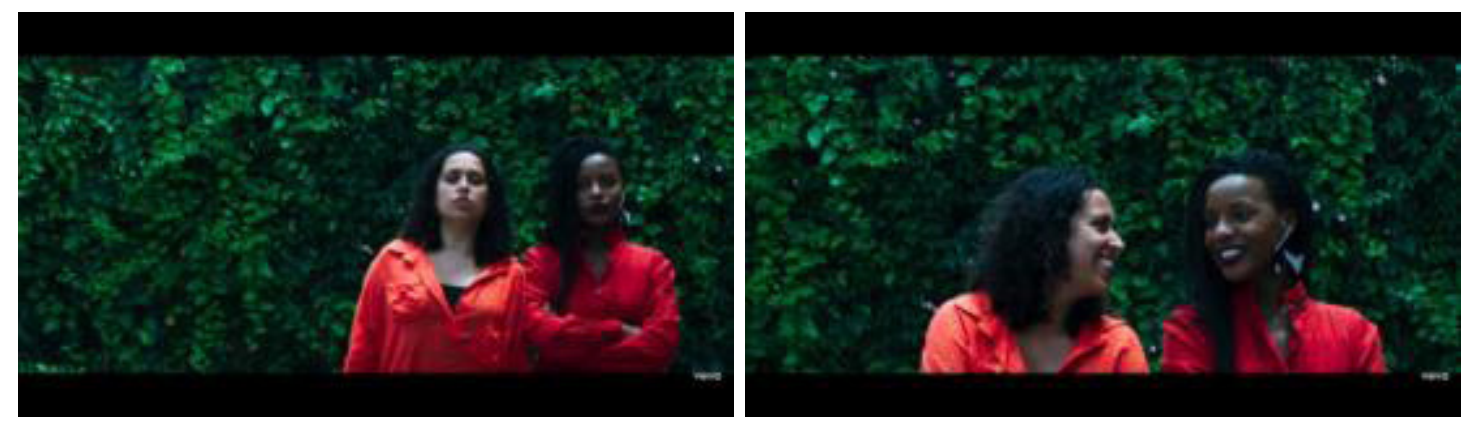

Fonte: youtu.be/mC_vrzqYfQc. Acesso em: 10 jan. 2019.

Em seguida, o casal com as roupas do mesmo modelo entrelaçam seus dedos de forma afetuosa (frame 18), em plano frontal contra-plongée, com as cabeças inclinadas em direção um ao outro (frame 19), de modo que o ângulo de seus pescoços e o tom negro de suas peles se mesclam com os galhos das árvores ao fundo, mostrados pelo movimento ascendente da câmera (frame 20). Embora a cena não mostre as raízes, elas se presentificam metaforicamente, construindo uma poética de honrar as próprias raízes por meio das relações afetivas afrocentradas, conduzindo a ramificações vivas, que escapam ao enquadramento em direção ascendente. Esse plano é intercalado e seguido pelo de um homem negro sem camisa, também em plano frontal, colocando um boné com a inscrição "LAB" e cruzando os braços, olhando fixamente para a câmera (frame 21).

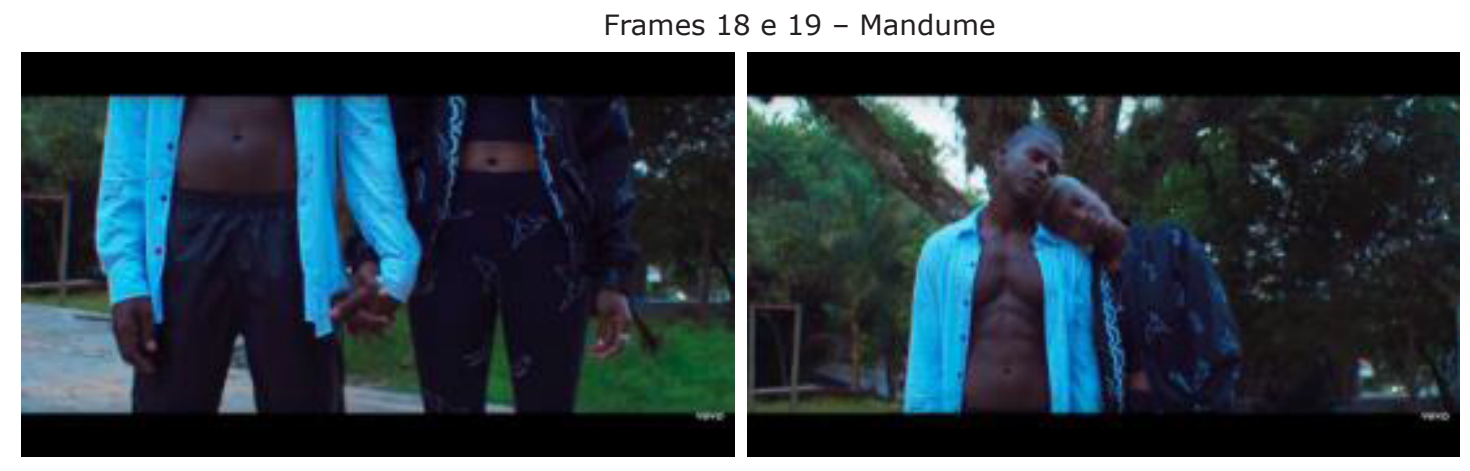

Fonte: youtu.be/mC_vrzqYfQc. Acesso em: 10 jan. 2019. 


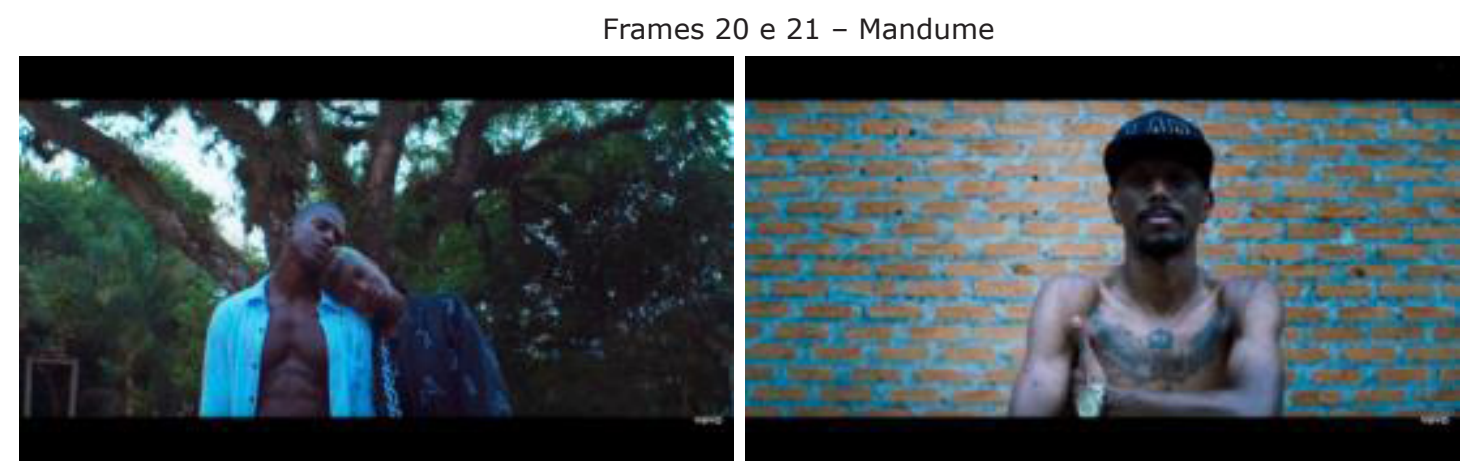

Fonte: youtu.be/mC_vrzqYfQc. Acesso em: 10 jan. 2019.

Seguem-se os solos de Muzzike, Raphão Alaafin e Emicida, que convoca o último refrão e deixa o microfone. A sequência intercala imagens dos rappers, em um cenário escuro sob uma luz avermelhada, dançando e cantando com olhares, expressões e gestos firmes em direção à câmera; que apontam, acionam, convocam e interpelam o espectador; de modo que a performance demanda atenção e cobra que esse espectador também se mova, se posicione. No bis, é mostrado um personagem branco, vestido e equipado como um policial da tropa de choque, com um capacete e um cassetete, em contra-plongée, sugerindo autoridade e poder (frame 22). De perfil, ele não encara a câmera/o espectador, mas olha fixamente para algo fora do quadro, mais além, à esquerda, de onde surgem duas mulheres, uma branca de cabelo curto, tingido de rosa, e a outra negra de cabelos cacheados (frame 23).

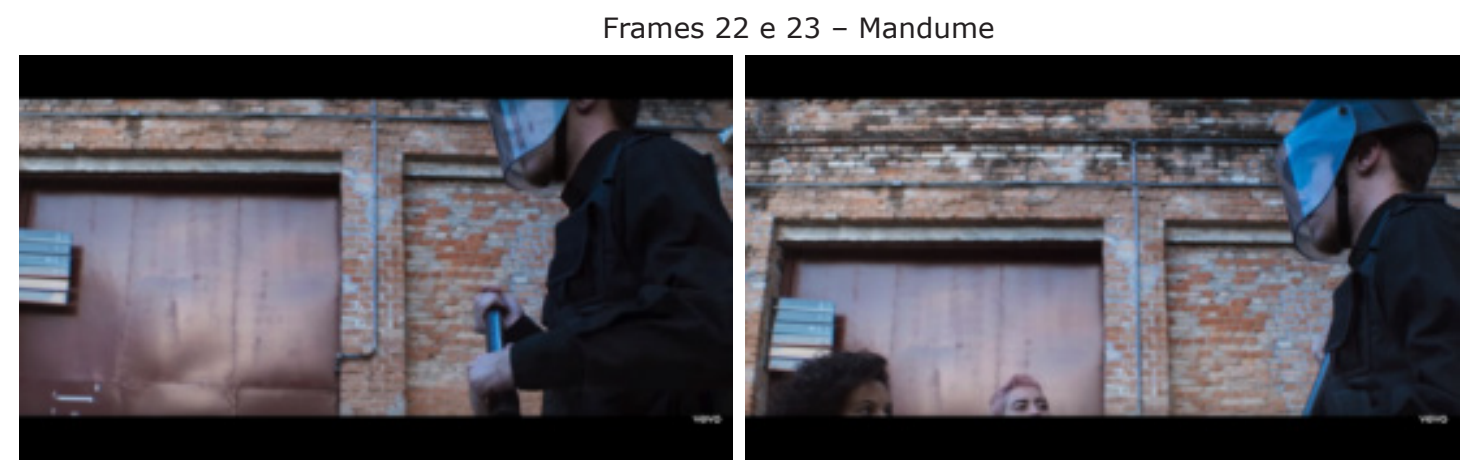

Fonte: youtu.be/mC_vrzqYfQc. Acesso em: 10 jan. 2019.

Inicialmente, apenas as testas das moças são enquadradas, demonstrando sua pequena estatura diante do policial. À medida que se aproximam dele, porém, ocupam um espaço cada vez maior no quadro, encarando-o fixamente com olhares de desafio. Verbalmente, o refrão articula a posicionalidade dos sujeitos por meio de uma demarcação entre "eles", "nós", "eu" e "eles", enfatizando os lugares sociais distintos, diferenciados em função da identificação racial. Visualmente, a moça negra avança e para em frente ao policial, em um confronto direto, enquanto a moça branca se posiciona entre eles, onde parece pronta para proteger a anterior (frame 24). O posicionamento dos personagens parece cercar o espectador, que se vê presente no embate, localizado entre a moça negra e o policial, e, portanto, intimado a se posicionar. A pista sobre o posicionamento adequado está à frente, na postura da moça branca que adentra o conflito e se aproxima do policial com o olhar firme (frame 25). As cenas finais mostram os rappers e os personagens, novamente privilegiando os planos frontais, reiterando o padrão de olhares, expressões faciais e posturas corporais, se encerrando com uma mulher negra de turbante, colares de contas e trajes de candomblé, olhando fixamente uma fogueira, que desaparece em fade out. 


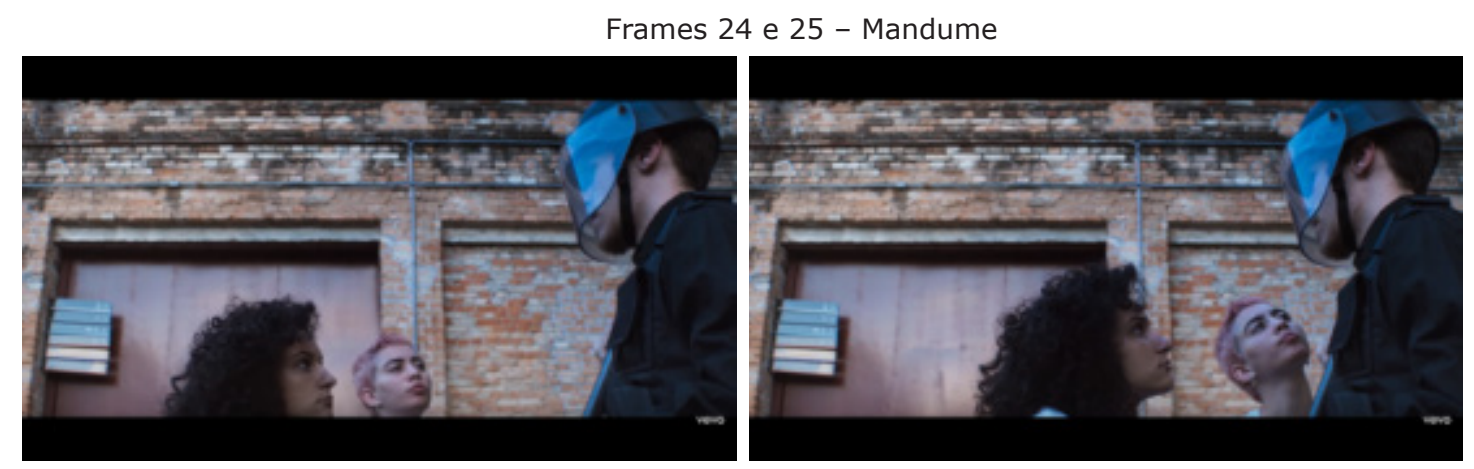

Fonte: youtu.be/mC_vrzqYfQc. Acesso em: 10 jan. 2019.

Partindo da multiestabilidade das metaimagens, proponho um deslocamento da minha posição como espectadora para explorar outras formas de interpretar essa materialidade audiovisual. Esse movimento se fundamenta em estudos sobre as relações raciais (FURTADO, 2019) e em conhecimentos construídos em outros espaços dos movimentos negros, bem como em minha própria vivência como pesquisadora negra. Nesse sentido, cabe uma reflexão sobre como as reivindicações e discursos dos movimentos negros são vistos pela sociedade hegemonicamente branca, instituindo restrições e constrangimentos às discussões sobre raça e racismo. Posturas nesse espectro cultural, ideológico e político, permeadas por noções racistas e pelo mito da democracia racial, apresentam o potencial de desconforto, discordância ou mesmo aversão às questões apresentadas em Mandume.

Nesse conjunto, a frase que encerra o refrão "eu quero é que eles se ----!", poderia ser interpretada como uma agressividade "gratuita" - em oposição a um protesto historicamente fundamentado e justificado - e como exemplo do "revanchismo" e "desejo de vingança" atribuídos aos movimentos negros em suas reivindicações pela igualdade racial. Através das lentes do preconceito linguístico, o uso da fala coloquial, gírias, palavrões e construções que fogem às normas de concordância verbal, poderia ser tomado como sinal de ignorância, analfabetismo e falta de conhecimento letrado. A demarcação da divisão entre brancos e negros, articulada verbalmente em comportamentos e ações específicas a "nós" e a "eles", ou seja, identidades construídas com base na identificação racial, poderia ser interpretada nos termos de outra acusação recorrente dos setores brancos contra os movimentos negros: o de perpetuar o racismo por meio da persistência em (re)construir identidades negras, em oposição à identidade nacional racialmente mestiça que busca branquear a população e apagar a "mancha negra". Nesse quadro, as posturas corporais, gestos e olhares seriam tomados como uma pretensa confirmação dos estereótipos racistas de "neguinho(a) atrevido(a)" e "preta(o) raivosa(o)", como demonstrações de uma agressividade animalesca e irracional supostamente natural às pessoas negras.

No entanto, para os espectadores que reconhecem que o racismo não apenas existe e persiste, mas determina nossa formação cultural, a interpretação será outra. Essa consciência sobre as relações raciais pode ser construída de diversas formas: a partir da observação crítica das experiências cotidianas; nos laços comunitários e familiares; na militância junto aos movimentos negros; na educação formal; na construção de saberes na música, arte e dança; ou, melhor, em todos ou muitos destes simultaneamente, possibilitando que permeiem uns aos outros e se enriqueçam mutuamente. Nesse espectro, encontrase, por exemplo, a construção do conhecimento posicionado a partir de lugares sociais estruturalmente subalternizados, enfatizando as conexões entre a subjetividade negra e a intelectualidade negra na consolidação do pensamento antirracista e decolonial. É esta vertente que retomo a seguir, evidenciando outro campo de possibilidades no encontro com o videoclipe.

Essa matriz de pensamento reveste a materialidade audiovisual de Mandume com efeitos e percepções ligados à resistência negra: são atribuídos aos olhares, expressões faciais, gestos e posturas corporais significações de altivez, seriedade, autoconfiança, força; desgosto, indignação, raiva, hostilidade e 
desconfiança em relação a quem olha; orgulho, desafio, provocação, questionamento, não-conformação e resistência. A intensificação desses semblantes ao longo do videoclipe evidencia a crescente compreensão sobre a violência racista e o veemente contraponto a esse sistema, metaforizados na interação entre a letra da música e a encenação desse padrão de olhares e posturas.

Historicizando as estruturas coloniais do ver, Paula Amad (2013) mobiliza contribuições teóricas de Jacques Leenhardt para enfatizar que um dos modos pelos quais as relações de poder da ordem colonial emergem na cultura visual é na materialização do direito de olhar sem ser olhado. Na visão da autora, alguns estudos que atentam para os olhares dirigidos à câmera tendem a constituir uma resposta ou contra-ataque visual (no original, "visual riposte"), definido como um gesto que vai além da análise formal ou estilística, incorporando o objetivo ético de devolver ou interrogar o olhar. Em sua concepção, o ato de devolver o olhar se manifesta em duas dimensões: no direcionamento do olhar dos sujeitos filmados para a câmera e para o espectador, e na interpretação desse olhar como um gesto de recusa à unidirecionalidade dos modos ocidentais de olhar para os Outros.

Nesse sentido, o movimento do olhar está relacionado ao ato de ver como ligado à agência para definir, responder, comunicar, produzir conhecimento e se posicionar diante dos regimes epistêmicos. Amad (2013) considera que, no contexto dos estudos pós-coloniais, a devolução do olhar materializa não uma inversão de papéis - que implicaria uma falsa simetria nas relações de poder entre sujeito e objeto, self e alteridade - mas a corporificação de um espaço de troca, interação, diálogo, em que os sujeitos subalternizados constroem suas próprias perspectivas, seus modos de ver e conhecer, sua própria visão de seu mundo. Para a autora, a potência da resposta visual reside em sua capacidade de interrogar a relação entre a visão colonial e o poder, partindo dos olhares dirigidos à câmera sem se limitar a eles, contemplando também o contexto político, histórico, cultural e intelectual que permeia a produção visual e os encontros com a visualidade.

A manutenção do plano frontal no videoclipe enfatiza a constituição das pessoas negras como sujeitos, então dotados do poder de reagir, se expressar, se manifestar, inclusive por outras formas que não a discursividade letrada - por meio da sensibilidade, da música, da performance corporal, da visualidade e oralidade, dos letramentos políticos alternativos articulados nos movimentos negros. As pessoas negras das encenações são muitas e diversas entre si, com diferentes tons de pele, texturas de cabelo e penteados, ocupando cenários diferentes. No entanto, todos mantêm o padrão de olhares, expressões e posturas frente à câmera, e os figurinos, apesar de trazerem diferenças, fazem parte da mesma coleção da grife. Expressase, assim, que não somos um bloco homogêneo como pretendido pelas narrativas coloniais: constituímos uma pluralidade de subjetividades, permanecendo, porém, unidos sob a vivência compartilhada da opressão racista; unidos em nossos posicionamentos e ações ao interrogar a branquitude.

Embora a letra afirme que "eles" querem que sejamos mais humildes e abaixemos a cabeça, o videoclipe não mostra nenhum semblante humilde, tampouco cabeças abaixadas. Essa discrepância entre a ordem verbalizada e a emergência visual demonstra que nós, pessoas negras, nunca aceitamos passivamente nossa própria opressão, mas fomos coagidos à subalternidade pelas estruturas de poder, pelo uso da força e de mecanismos institucionais de exclusão, mascarados por narrativas históricas que naturalizam essa dominação. Assim desde a colonização, em que nossos ancestrais não vieram para as Américas voluntariamente, mas sequestrados e vitimados pelo tráfico intercontinental de pessoas escravizadas. Desde então, fomos forçados ao apagamento da nossa história, cultura e epistemes em um processo de assimilação que nos reservou um lugar social de subalternidade como única forma de incorporação pacífica à sociedade, lado a lado com políticas genocidas e de encarceramento em massa (FURTADO, 2019). Diante desse cenário, não restam outros olhares e posturas possíveis que não os da hostilidade, desafio e resistência.

Não se pretende construir uma fórmula totalizante e dicotômica sobre as interpretações dessa narrativa audiovisual, mas identificar duas matrizes opostas que constroem imaginários conflitantes, que 
permeiam e dão sentido aos processos de socialização. É um embate presente nas discussões, saberes e representações sobre as interações entre pessoas negras e brancas, sobre as dinâmicas estruturais e ramificações do racismo na vida social. Esses imaginários estão em interação constante nos processos culturais de apropriação, adaptação, negociação e resistência. É precisamente este conflito que se vê em Mandume, a disputa simbólica que se repete em nossa vida cotidiana e ocupa lugar central na luta antirracista.

Os versos "eles querem que alguém/que vem de onde nóiz vem/seja mais humilde, baixe a cabeça" evocam, nos sujeitos espectadores negros, memórias de suas próprias experiências com o racismo que representam essas ordens - seja em relações interpessoais ou, mais amplamente, na dimensão estrutural do confinamento à subalternidade. Esses versos também podem evocar imagens de pessoas negras em posições de inferioridade, cristalizadas nos imaginários por meio das representações estereotipadas na televisão, cinema, pintura e literatura; bem como nas situações cotidianas, considerando que, em função do racismo estrutural, é comum que as profissões tidas como subalternas sejam ocupadas majoritariamente por pessoas negras.

O choque entre esses imaginários e o conjunto das posturas altivas e olhares confiantes em referência ao rei Mandume evidencia os gestos de resistência que desafiam a ordem racista. A referência ao desejo da sociedade branca, de que as pessoas negras finjam que esqueceram "a coisa toda", evidencia que o conflito não se limita à esfera individual, mas diz respeito à continuidade histórica que estrutura a sociedade. Se a branquitude narra as relações raciais em seus próprios termos, ocultando seletivamente o passado e a forma como o sistema racista se articula no presente, os próprios atos de lembrar, investigar os rastros e produzir conhecimento sobre essa continuidade histórica são gestos de resistência - manifestados nas expressões de resiliência, raiva, hostilidade e desafio. O refrão encenado não por um sujeito único, mas sempre por grupos, enfatiza a relação entre as experiências pessoais e sua dimensão coletiva.

Apesar do controle discursivo operado pela sociedade hegemonicamente branca - expresso na verbalização do que "eles querem" -, escapam pela visualidade elementos que demonstram a resistência à dominação da ordem racista. Enquanto as vozes do refrão revelam que "eles" querem nossa subalternidade e inferioridade, a composição visual mostra quem somos e o que queremos: nos cenários, cabelos e figurinos repletos de referências à sobrevivência e valorização da cultura e estética negras; na contraposição entre os gestos de hostilidade para a câmera e os gestos de afeto, cumplicidade e respeito entre si; nas expressões corporais e faciais de orgulho, força, altivez, resistência. A interação entre as dimensões verbal e visual revelam a disputa entre opressão racial e resistência, continuamente tensionada até a ira da explosão no verso "eu quero é que eles se ----!", acompanhado dos gestos.

A disputa construída no refrão de Mandume, portanto, evidencia as relações entre a esfera individual e a coletiva, lançando luz sobre as dimensões sociais, políticas e estruturais de nossas vivências e construções identitárias. Esse movimento articula relações de reconhecimento e pertencimento entre pessoas tão diversas, com relatos tão distintos sobre as formas como conhecem e compreendem a opressão racial. O refrão, cantado por todos, demonstra como a multiplicidade de experiências do racismo - entrecruzadas com a opressão de gênero; letramento, representação histórica e violência epistêmica; LGBTQfobia; desigualdade de classe; intolerância religiosa - encontram um terreno comum, compartilhado, na luta antirracista.

Em entrevista à Ponte ${ }^{8}$ sobre Mandume, Emicida afirma: "Desde a primeira vez em que entrei em contato com sua história, acreditei que ela podia ser uma metáfora pros vários descendentes de reis e rainhas que seguem cabisbaixos pelo mundo sem saber de sua grandeza", destacando o objetivo de levantar a cabeça das pessoas negras por meio do conhecimento sobre sua ancestralidade. Nesse sentido, não se trata apenas de linhagem direta: na diáspora negra, devido a suas condições de formação, em que

8 Disponível em: bit.ly/2DObZvY. Acesso em: 26 nov. 2018. 
o tráfico intercontinental de pessoas escravizadas impossibilitava traçar diretamente a própria origem no continente africano, a ancestralidade assume um sentido mais amplo de coletividade negra e tributo às pessoas que enfrentaram a luta antirracista antes de nós.

Na mesma entrevista, Emicida destaca que conheceu a história de Mandume não por meio da educação formal, mas ouvindo a história de um amigo e, a partir de então, pesquisando mais. Ao trazer o nome de Mandume sem contar sua história, o videoclipe instiga que seus espectadores façam o mesmo, encontrando uma fotografia do início do século XX (fotografia 1) que enriquece o repertório dos espectadores e, por consequência, a experiência visual do videoclipe, evidenciando a origem da postura corporal performada pelos músicos, ativistas e artistas negros que encenam o legado de Mandume de braços cruzados e cabeça erguida. Por meio dos planos frontais, bem como dos olhares, expressões faciais e posturas corporais de altivez e orgulho, o videoclipe evidencia o reconhecimento das pessoas negras em suas dimensões individual e coletiva, histórica e contemporânea, subjetiva e epistemológica.

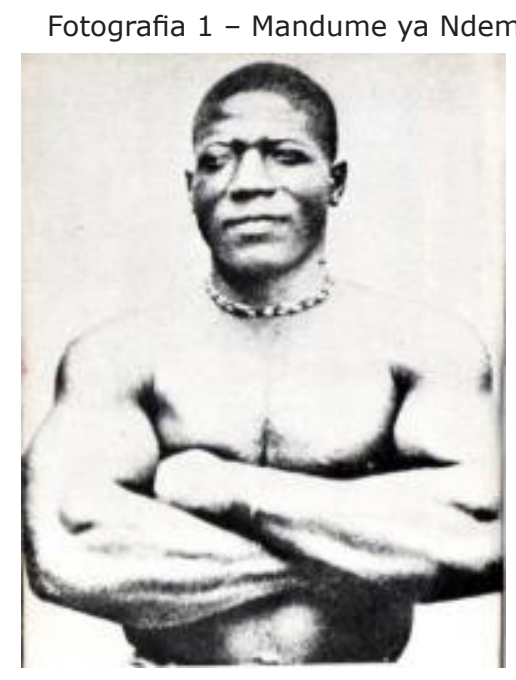

Fonte: bit.ly/2DObZvY. Acesso em: 26 nov. 2018.

A figura de Mandume, então, emerge como inspiração: a subjetivação política antirracista é o despertar do Mandume em cada um de nós. Essa associação é enfatizada pela própria composição da música, que traz o nome no título, mas opta por não contar a história deste rei, dando lugar aos relatos testemunhais da opressão racial entrecruzada com outros eixos de subalternização conforme vivida pelos rappers em suas interações cotidianas com a branquitude. Embora existam interpretações ligadas à reiteração de imaginários e estereótipos racistas, esses relatos na experiência visual apresentam o potencial de articular relações de reconhecimento, pertencimento, identificação das pessoas negras com a coletividade negra, ou de convocar posicionamentos de responsabilidade das outras pessoas diante do racismo.

Estão em jogo, então, dois imaginários conflitantes: o da figura negra humilde e de cabeça baixa, evocado pela verbalização do que "eles querem" e reforçado por regimes de representação racistas; e aquele da figura do rei Mandume, evocado pela performance visual dos sujeitos negros e por artistas, músicos, professores, ativistas dos movimentos negros e demais pessoas negras em posições de destaque na vida social. Esses imaginários se relacionam à perspectiva dos sujeitos sobre questões raciais, à consciência sobre as dimensões cultural e estrutural do racismo e às expectativas sobre o comportamento e posicionamento dos sujeitos negros em suas interações sociais. Tais imaginários, que se encontram em circulação na sociedade, entremeados às visões dos sujeitos e às formas de produção cultural e regimes de representação, permeiam o encontro com a materialidade audiovisual e são trazidos à tona mediante a interpelação da metaimagem. 
Esses imaginários dizem também das relações de poder que definem o conhecimento eurocêntrico como superior às matrizes de pensamento africana e indígena, que continuam a ser silenciadas e marginalizadas. Mandume interroga e critica essa matriz dominante, que se pretende universal e igualitária ao mesmo tempo em que exclui e violenta determinados sujeitos. Em meio a esse genocídio como processo social e histórico, a racionalidade eurocêntrica destitui os grupos subalternizados até mesmo do poder de reivindicar seu reconhecimento, ao descartar suas formas de se comunicar, expressar e argumentar, seus modos de fazer política e suas epistemes, definindo-as como ilegítimas e inferiores perante o conhecimento letrado. Nesse sentido, a metaimagem permitiu revelar as hierarquias de poder estabelecidas não apenas entre regimes racializados de representação, mas entre tradições epistêmicas, entre modos de ver/conhecer e se dar a ver/conhecer em sociedade.

Mais do que protestar o genocídio da população negra, Mandume contesta o processo de epistemicídio contra nossas tradições de conhecimento, nossas formas de sociabilidade, argumentação, expressão e prática política. Desse modo, Mandume reivindica a legitimidade, validade e autonomia do nosso pensamento, o reconhecimento dos nossos modos de articular conhecimento e resistência por meio da música, performance, produção artística, oralidade e visualidade, bem como as rupturas que a fonte epistemológica negra provoca ao se inserir nos espaços consolidados do saber. Emerge, assim, a cena de um conflito entre esses dois modos distintos de se pensar, de se constituir como sujeitos, de se narrar, de se dar a ver em sociedade - evidenciando os movimentos negros como plenamente capazes de se autodefinir, nomear suas opressões e construir perspectivas, visões de mundo e ações políticas por meio de suas próprias referências e epistemes.

\section{Considerações finais}

A análise dos refrões de Mandume evidenciou uma narrativa sobre a construção das imagens e do conhecimento sobre as relações raciais, sobre a atuação dos movimentos negros como protagonistas da reconstrução desses regimes do visível e epistemes - revelando a resistência não apenas dos sujeitos negros individualmente, mas como coletividade, na riqueza epistemológica negra. Aliada aos Estudos Visuais, a análise de estilo televisivo permitiu abordar a visualidade de movimentos sociais que interrogam e desafiam, que usam o olhar, o tom de voz e a expressão corporal como instrumentos de interpelação. $\mathrm{O}$ arranjo de imagem e som revelou questões mais amplas sobre como as pessoas negras são vistas e mostradas, e as implicações sociais dos efeitos performativos de ser olhado, olhar de volta e interpelar com esse olhar.

Nessa experiência visual, a continuidade histórica do racismo é apresentada a partir do ponto de vista de sujeitos negros, convocando e interpelando o observador. Como destacado por Mitchell (2009), ao devolver o olhar do espectador, a imagem devolve também a pergunta, interrogando-o sobre seu autoconhecimento e convidando-o a ocupar um lugar, a assumir um posicionamento frente à problemática ali construída. O videoclipe intensifica o potencial das imagens em interpelar esse observador, evidenciando o caráter racializado das assimetrias socialmente construídas, demandando que se conheça e se posicione em sua subjetividade diante das questões raciais.

Reconhecer o racismo e a forma como esse sistema opera desigualdades, violências e privilégios é condição indispensável para esse diálogo. O encontro com a alteridade - com seu conceito abstrato e com os sujeitos representativos dessa noção, que ocupam esse lugar social - convoca os sujeitos a refletirem sobre suas próprias identidades, sobre seus posicionamentos frente a essa alteridade. Nesse sentido, a instrumentalização da posicionalidade articulada no videoclipe por meio da demarcação explícita de "eles", "nós", "eu" e "eles" interage com a dimensão visual de modo a enfatizar seu caráter como desestabilizador da ideia de um sujeito único, neutro, universal. 
O videoclipe reivindica a legitimidade e agência de nossos olhares oposicionais, conforme proposto por bell hooks ${ }^{9}$ (1992), como atos insubordinados de sujeitos plenos que encaram e interrogam criticamente, contestando o olhar do outro, nomeando e afetando a realidade observada. Nesse sentido, os olhares oposicionais não se limitam à postura frente aos produtos culturais, mas operam também diante das epistemes hegemônicas - por meio da oralidade e visualidade da produção cultural e dos instrumentos teórico-metodológicos dos movimentos sociais incorporados ao ambiente científico, junto às presenças negras e ao ativismo antirracista, produzindo novos letramentos que enriquecem os saberes acadêmicos e os aproximam da justiça social.

Nos testemunhos de sobreviventes do genocídio e epistemicídio negro e em seus próprios aspectos formais, o videoclipe busca romper com as cruéis e elitistas normas da argumentação política pacifista, cordial e passiva que rege os ideais da esfera pública da branquitude. Esses regimes de silenciamento tornam necessário mostrar que não somos contemplados por essa matriz da racionalidade eurocêntrica que forja a noção de igualdade enquanto nos exclui, subordina, extermina e silencia. A exclusividade dessa matriz eurocêntrica é questionada, demandando que nos ouçam em nossos modos de narrar, afetar, sensibilizar e comunicar, para que compreendam a natureza violenta das relações raciais; para que entendam que, se protestamos e reivindicamos de maneira tão veemente é porque somos violentados cotidianamente nas interações com a branquitude, física, verbal e simbolicamente.

A ausência dessa compreensão, inclusive em relação à responsabilidade das pessoas brancas autodeclaradas de esquerda ou progressistas, é um obstáculo à igualdade racial. Tais alianças do grupo racial dominante articulam seu acesso privilegiado às oportunidades sociais na continuidade de preconceitos, violências, processos de exclusão, regimes de representação e visibilidade que mantêm naturalizado o nosso genocídio - que, como vimos em Mandume, é também um processo de epistemicídio. O videoclipe convoca à ruptura com a invisibilização do racismo em suas diversas manifestações, entrecruzadas com outras formas de subalternização como sistemas interligados de poder, principalmente na dimensão das tradições de conhecimento.

Desse modo, mais do que apenas tratar dos regimes de visibilidade e das normas racializadas de produção de imagens, a metaimagem de Mandume revela aspectos sobre o apagamento e hierarquização de epistemes em nossa sociedade. Em um rico esquema de autorreferencialidade, Mandume reitera, por meio de seus próprios aspectos formais, a importância dos modos de produção de conhecimento que estão fora do circuito intelectual hegemônico, acadêmico, dos livros de história, da razão eurocêntrica. Além de tomar posse da palavra e das imagens, do direito de se autodefinir e produzir saberes posicionados a partir da subjetividade dos lugares sociais negros, o videoclipe evidenciou esses processos de conflito e exclusão por meio de sua própria materialidade, demonstrando a oralidade e visualidade articuladas no rap como uma fonte de conhecimento sobre os impactos do racismo na sociabilidade das pessoas negras, sobre as estratégias de intervenção e resistência negra. O videoclipe legitimou e fortaleceu as matrizes de pensamento decoloniais, evidenciando seu potencial para revelar as condições históricas que instituem as interações sociais racializadas, as categorias de poder e as hierarquias entre epistemes.

\footnotetext{
${ }^{9}$ A autora, chamada Gloria Watkins, adotou o nome da avó como pseudônimo e pede que sua grafia seja feita em letras minúsculas, como forma de destacar não sua figura individual, mas o conteúdo de sua produção.
} 


\section{Referências}

AMAD, Paula. Visual Riposte: Looking Back at the Return of the Gaze as Postcolonial Theory's to Film Studies. Cinema Journal, v. 52, n. 3, p. 49-74, 2013.

BREA, José Luis. Los estudios visuales: por una epistemología política de la visualidad. In: BREA, José Luis (Ed.). Estudios Visuales: La epistemología de la visualidad en la era de la globalización. Madrid: Akal Estudios Visuales, 2005.

BUTLER, Jeremy. Television Style. New York: Routledge, 2010.

FURTADO, Lucianna. Mandume: Rastros da diáspora na reconstrução de memórias e identidades negras no rap. Mestrado (Comunicação e Sociabilidade Contemporânea) - Faculdade de Filosofia e Ciências Humanas da Universidade Federal de Minas Gerais, 2019.

HOOKS, Bell. Black looks: race and representation. Boston: South End Press, 1992.

JANOTTI JÚNIOR, Jeder; SOARES, Thiago. O videoclipe como extensão da canção: apontamentos para análise. Revista Galáxia, n. 15, p. 91-108, jun. 2008.

MANDUME. Emicida feat. Drik Barbosa, Amiri, Rico Dalasam, Muzzike, Raphão Alaafin. Direção: Gabi Jacob. Laboratório Fantasma, 2016. 8 minutos e 47 segundos. Disponível em: youtu.be/mC_vrzqYfQc. Acesso em: 10 jan. 2019.

MELO ROCHA, Rose; PORTUGAL, Daniel. Como caçar (e ser caçado por) imagens: entrevista com W. J. T. Mitchell. E-Compós, v. 12, n. 1, jun. 2009.

MITCHELL, William John Thomas. Metaimágenes. In: MITCHELL, William John Thomas. Teoría de la imagen: Ensayos sobre representación verbal y visual. Madrid: Ediciones Akal, 2009.

MITCHELL, William John Thomas. ¿Qué quieren las imágenes? Una crítica de la cultura visual. Buenos Aires: Sans Soleil Ediciones Argentina, 2017.

MITCHELL, William John Thomas. No existen medios audiovisuales. In: BREA, José Luis (Ed.). Estudios Visuales: La epistemología de la visualidad en la era de la globalización. Madrid: Akal Estudios Visuales, 2005.

ROCHA, Simone Maria. Estudios visuales y estilo televisivo: porque no existen medios puramente visuales. Chasqui - Revista Latinoamericana de Comunicación, n. 135, p. 297-316, ago./nov. 2017.

ROCHA, Simone Maria. Os visual studies e uma proposta de análise para as (tele)visualidades. Significação: Revista de Cultura Audiovisual, v. 43, n. 46, p. 179-200, dez. 2016.

SOARES, Thiago. A estética do videoclipe. João Pessoa: Editora da UFPB, 2013.

SOARES, Thiago. O videoclipe como articulador dos gêneros televisivo e musical. Anais do IX Congresso Brasileiro de Ciências da Comunicação da Região Nordeste, 2007. Disponível em: bit.ly/2A42Trt. Acesso em: 17 nov. 2018. 